\title{
Microprocessor-controlled monitoring of honeybee flight activity at the hive entrance *
}

\author{
MH Struye 1, HJ Mortier 1, G Arnold 2, C Miniggio 3, R Borneck ${ }^{3}$ \\ 1 Lowland Electronics bvba, Langekoeistalstraat 2, 8432 Leffinge-Middelkerke, Belgium; \\ 2 Laboratoire de Neurobiologie Comparée des Invertébrés, INRA-CNRS (URA 1190), \\ BP 23, 91440 Bures-sur-Yvette; \\ 3 Institut Technique de l'Apiculture, rue de la Guyonnerie, 91440 Bures-sur-Yvette, France
}

(Received 23 September 1993; accepted 7 March 1994)

\begin{abstract}
Summary - An important parameter in evaluating the activity of a honeybee colony is given by the number of bees leaving and entering the hive as a function of time. The microprocessor-controlled counter described here presents many advantages over previous counting devices. The counter fits the standard hive measurement ( $10 \mathrm{combs}$ ), and provides access to the hive via 32 bi-directional channels. The very small infrared detectors in each channel are only $0.1 \mathrm{~mm}$ apart, and are controlled by an asynchronous sequential algorithm, which improves the counter's precision. Results of measurements of the daily activity of honeybee colonies under different conditions (normal, in the presence of pesticides, or during swarming) are presented.
\end{abstract}

Apis mellifera / bee counter / flight activity / swarming / pesticides

\section{INTRODUCTION}

Bee activity at the hive entrance is dependent on many factors, such as climatic conditions, colony health, and the presence of an adequate food supply. The capacity to measure this activity in relation to varying environmental conditions thus constitutes an important factor in the better understanding of honeybee biology, even more so when environmental changes occur that directly threaten the life of the colony, such as the phytosanitary treatment of crops, par- ticularly when cultures are in full bloom. Even when authorized pesticides are used, the homologation tests have only been carried out in the artificial environment of the laboratory, and thus only take acute pesticide toxicity into account, thereby generally neglecting their sublethal and long-term effects.

The need for a bee counter was recognized quite early on; different solutions have been proposed, such as a pure mechanical solution (Chauvin, 1976), or a detection system using photoelectric cells (Brittain,

* We dedicate this article to Pr Rémy Chauvin on occasion of his 80 th birthday. 
1933; Spangler, 1969; Burril and Dietz, 1973; Erickson et al, 1975; Buckley et al, 1978; Pickard and Hepworth, 1979; Rickli et al, 1989; Liu et al, 1990). Most systems use different channels for incoming and outgoing bees and are theoretically suited to monitor flight activity within a given period of time. These measurements have often been lacking in precision for several reasons. For example, there is the problem of resolution: when one bee follows another within a short distance they are not perceived separately by the counting mechanism. Furthermore, bee movement in the channels can be erratic and thus result in a false count. $A$ necessary improvement in the counting method therefore lies in finer resolution and through the use of an intelligent algorithm allowing the elimination of erratic bee movements in the channels. Finally, counter size and the number of in/out channels should be adapted to the size of normal hives and not to small experimental hives (Liu et al, 1990).

Technological progress has made possible the construction of a new type of bee counter incorporating the required improvements. Here we present a new device,
BeeSCAN (Lowland Electronics), with some examples of its potential in the study of honey-bee activity at the hive entrance under different conditions.

\section{MATERIALS AND METHODS}

\section{Counter description}

The BeeSCAN counter equipment is composed of 4 different modules: the bee counter; a computer interface; a power supply; and a driver software.

\section{Bee counter}

Bee movement detection takes place in 32 bidirectional channels (fig 1). Each channel measures $15 \times 6.5 \times 8 \mathrm{~mm}$ (length $x$ width $x$ height). Its length $(15 \mathrm{~mm})$ approximately equals that of 1 honeybee and prevents the encounter between incoming and outgoing bees within a channel. The distance between adjacent channels is $12.7 \mathrm{~mm}$.

Movement detection inside a channel is effected via an infrared beam, which hits a dual photoreceptor (fig 2). The 2 radiation-sensitive

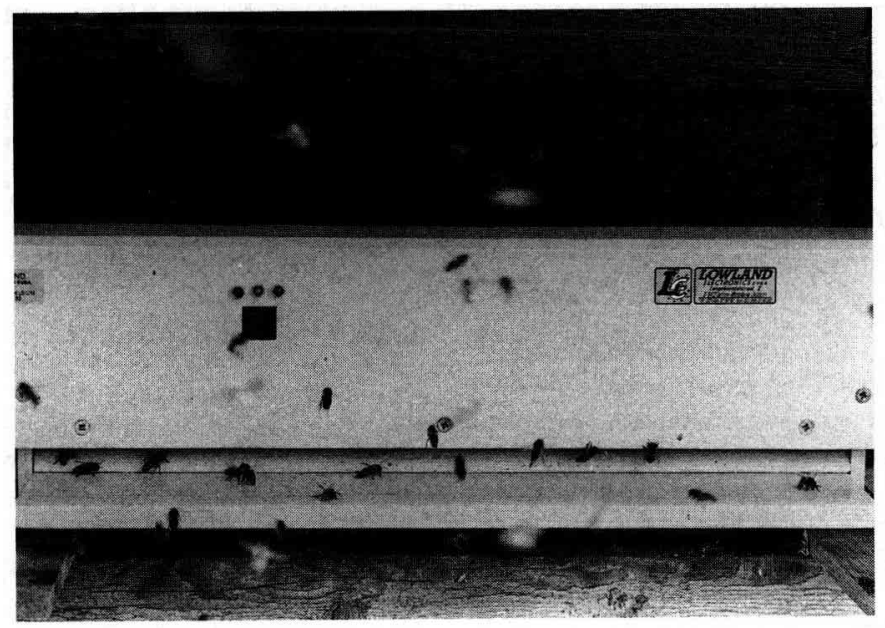

Fig 1. Frontal view of a bee counter placed in front of a hive (10-frame Dadant). 


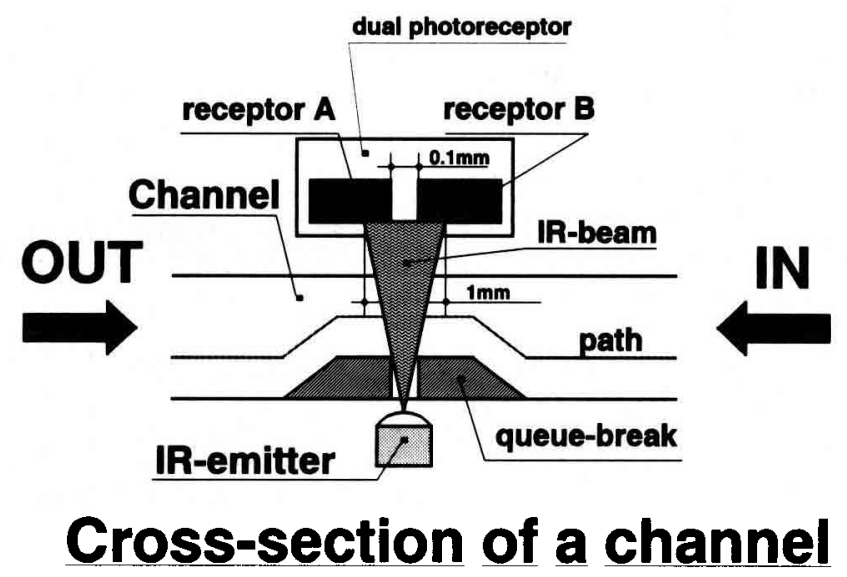

Fig 2. Schematic drawing of a cross-section of an in/out channel showing the location of the infrared emitter and the 2 detectors. The 'queue-break' is a slight narrowing of the channel leading to better separation between successive bees.

areas in this photoreceptor are only $0.1 \mathrm{~mm}$ from one another. This gives a certain resolution at 1 $\mathrm{mm}$, which can be increased to about $0.5 \mathrm{~mm}$ by individual fine tuning of the light-beam intensity. Which of the 2 received beams is interrupted first indicates the direction of the movement.

The BeeSCAN counter is protected by a tough, weather-resistant PVC casing and has already been tried and tested under field conditions.

\section{Interface}

One or more counters can be connected on a common serial line to the COM1 serial computer port of a host computer (PC). This common line is a simple twisted pair line, driven by a balanced current driver which guarantees reliable transmission up to $100 \mathrm{~m}$. It should enable the host computer to be set up in a reasonably safe and dry environment.

\section{Power supply}

The counter can be battery (12 V) or main current operated. Battery power limits its usage in time to about $3 \mathrm{~d}$. This ample time limit is possible due to CMOS technology. A counter consumes about $2.4 \mathrm{~W}$.

\section{Software}

The software consists of 2 modules: a counter driver and a data module.

\section{Counter-driver module}

The counter module is set up on a floppy-disk system. This has been done such that the counting process, which is mostly unattended, starts up again automatically after a power failure without the need for operator intervention. The measured values are regularly saved on disk so they do not get lost as a result of power failure or the computer being accidentally switched off. A parameter text file on disk provides the possibility of introducing a particular site identification code and selecting the sampling interval. The user can choose the sampling interval, with a minimum of $1 \mathrm{~min}$, and the microcontroller continues the counting during the writing process. At the end of the interval, the bee counter delivers the numbers of incoming and outgoing bees dur- 
ing this interval. The computer stores this information, together with the real time in a ASCII file. There is no interruption of the counting process during datalogging. In our experiments this interval was set to $5 \mathrm{~min}$.

The only limit of file size is the size of the floppy or hard disk on which it is stored. For everyday use the program automatically creates a new file.

A floppy-disk system is used as the boot drive instead of a hard disk so that the data files (of the last days) can be removed without stopping the computer program.

Every channel is checked 2000 times/s, that is for the 32 channels, 64000 times/s. The counter only validates a count when a bee leaves a channel. If one channel is blocked (by a dead bee, for example) there is no registration, because there is no activity, and the device is equipped with an indicator which informs the experimenter of this abnormality. The obstruction can then easily be removed.

\section{Data module}

The data module is menu driven and allows the measured data to be: i) viewed on screen; ii) printed; and iii) converted to an ASCII file that can be read by other software packages (eg, Foxpro, Excel, and DBase).

\section{Experimentation}

\section{Measuring daily activity of a honeybee colony}

The Dadant hives were equipped with 10 combs and populated by a normal production colony of Apis mellifera mellifera honeybees (40 000 to 50000 bees). Measurements were made in field tests both under normal conditions and during phytosanitary treatment. In all experiments, data (incoming and outgoing bees) were sampled at 5min intervals.

Flight activity was registered under normal conditions in both Leffinge (Belgium, $5 \mathrm{~km}$ from the North Sea coast) and Bures-sur-Yvette (France, $20 \mathrm{~km}$ from Paris).

Testing for the influence of crop treatment was performed at 3 locations when the crop was in full flower, with 3 different mixtures of insecticides and fungicides.

\section{Experiment 1}

In August 1990, near Chateaudun (Eure-et-Loir, France), a hive was placed $100 \mathrm{~m}$ from a field of white mustard (Sinapis alba) treated with a mixture of the fungicide Sportak 45 (prochlorase) and the insecticide Décis (deltamethrine) over 1 and $0.5 \mathrm{l} / \mathrm{ha}$, respectively. Spraying took place between 10:40 and 11:10 $\mathrm{h}$. The temperature was $20^{\circ} \mathrm{C}$, and the wind speed $2 \mathrm{~m} / \mathrm{s}$.

\section{Experiment 2}

In April and May 1991, near Mantes-la-Jolie (Yvelines, France), a hive was placed $100 \mathrm{~m}$ from a field of colza (Brassica campestris) treated with a mixture of the fungicide Konker (vinchlozoline + carbendazime) and the insecticide Décis (deltamethrine) over 1 and $0.2 \mathrm{l} / \mathrm{ha}$, respectively. Spraying began at $11: 20 \mathrm{~h}$. The temperature was $10^{\circ} \mathrm{C}$ and the wind speed $4 \mathrm{~m} / \mathrm{s}$.

\section{Experiment 3}

In May 1992, near Arras (Pas-de-Calais, France), a hive was placed $100 \mathrm{~m}$ from a field of colza (Brassica campestris) treated with a mixture of the fungicide Eria (difenoconazole + carbendazime) and the insecticide Karate (lambdacyhalothrine) over 2.5 and $0.1 \mathrm{l} / \mathrm{ha}$, respectively. Spraying began at 9:50 h. The temperature was $14^{\circ} \mathrm{C}$ and the wind speed $2 \mathrm{~m} / \mathrm{s}$.

\section{Reliability study}

In the spring of 1991, 2 reliability studies were set up at Bures-sur-Yvette. For this test, a closed hive was placed within a fine-mesh wire cage. Food sources (honey, pollen, flowers) were placed in the cage to stimulate bee activity. At the beginning of the experiment, free access was given to the hive entrance and counting began. After about 6 or $7 \mathrm{~h}$ counting was terminated and the hive entrance was closed again. All bee (dead or alive) remaining in the cage, were counted. It was therefore possible to compare this number with the results of the computer-controlled counting. In parallel to this experiment a second counter was installed in another colony placed in a field for comparison of flight activity. 


\section{RESULTS}

\section{Daily colony activity}

\section{Sunny day}

Figure 3 shows an example of honeybee flight activity pattern on a sunny day (28/04/91, Bures-sur-Yvette, no rain, average wind velocity $2.5 \mathrm{~m} / \mathrm{s}$ ).

\section{Outgoing bees}

The worker bees began to leave the hive at about $8: 30 \mathrm{~h}$ at a rate of 10 bees $/ 5 \mathrm{~min}$ (abbreviation: 10 bees). Around 10:15 $\mathrm{h}$ this number increased to 50 bees, while the ambient temperature was $9^{\circ} \mathrm{C}$. Activity continued to increase until 13:45 $\mathrm{h}$ (2 600) and remained high until about 17:00 $\mathrm{h}$. After that time, the number of incoming bees was greater than that of outgoing bees. All activity ceased around 21:45 $\mathrm{h}$ (< 10 bees). Oscillations appeared in the curve, demonstrating that a large number of honeybees left the colony in waves. This was probably due to variations in local meteorological conditions (gusts of wind, passing clouds, etc) or to recruitment of a group of worker bees by returning scout bees.

\section{Incoming bees}

The flight activity pattern of the incoming bees had the same general appearance as that for the outgoing bees, with a peak around 14:00 h. Oscillations were less pronounced, probably because the timing of the bees' returns were spread out due to the different distances they had covered.

\section{Cumulative curve of bees outside the hive}

The total number of bees outside the hive increased during the day, with some oscillations related to the waves of outgoing bees. The number of outgoing bees was particularly high around 14:00-17:00 h ( 5600 bees), with a peak of 6000 insects at $14: 45 \mathrm{~h}$. At the end of the day, 1900 bees did not return to the hive; this represented $1.5 \%$ of the total number of flights (127 859 bees).

\section{A cold cloudy day}

Figure 4 shows an example of honeybee flight activity pattern on a cold cloudy day

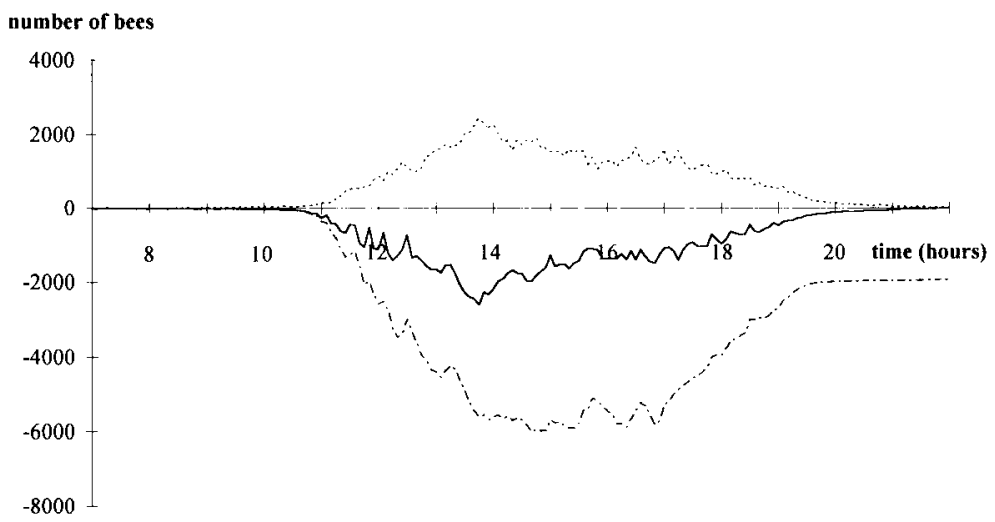

Fig 3. Daily activity of a bee colony on a sunny day (28/04/91) at Bures-sur-Yvette (France). Solid line: outgoing bees; dotted line: incoming bees; dashed/dotted lines; cumultative number of bees still out of the hive. 


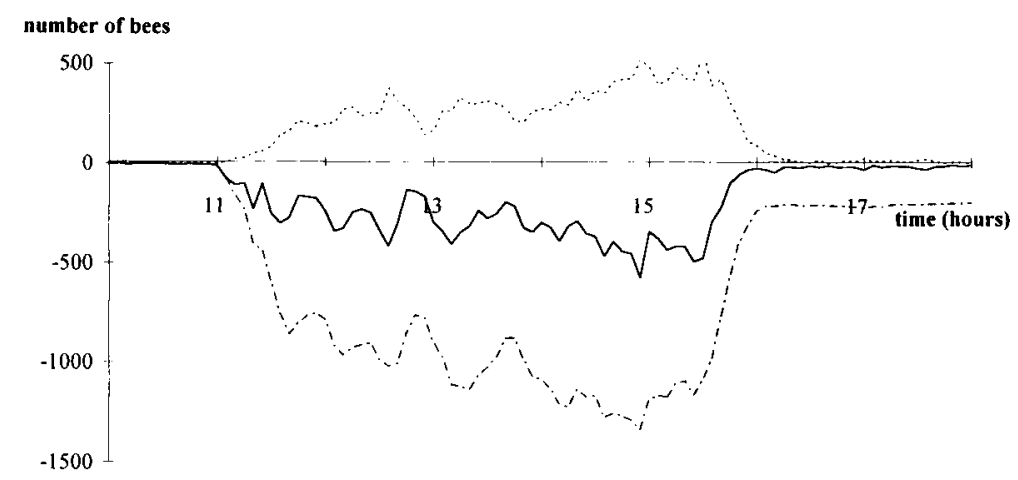

Fig 4. Daily activity of a bee colony on a cold cloudy day (31/03/91) at Leffinge (Belgium). Legend as in figure 3 .

(31/03/91, Leffinge, mean temperature $5^{\circ} \mathrm{C}$, no rain, very light wind).

Colony activity was very low. The first flights began around 11:00 $\mathrm{h}$ (10 bees) with a maximum occurring at 15:00 $\mathrm{h}$ (570 bees). As was the case for a sunny day, oscillations appeared in the curves, mainly for the outgoing bees and for the cumulative curve.
At the end of the day, 190 bees did not return to their hive, ie $1.1 \%$ of the 17303 flights.

\section{Flight activity during swarming}

Figure 5 shows the flight activity pattern during a sunny day on which the colony unex-

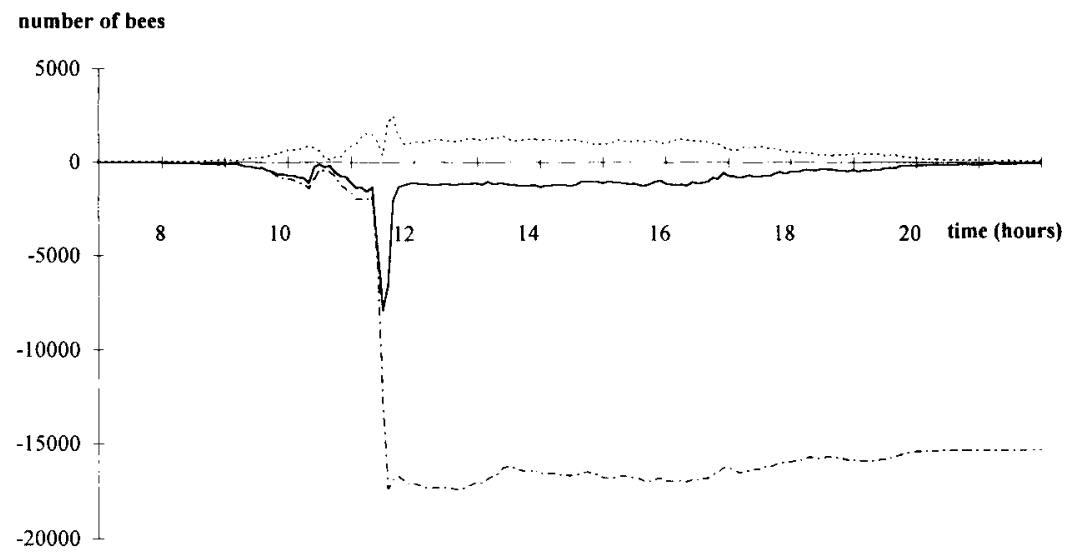

Fig 5. Flight activity of a bee colony during swarming (13/05/91). Legend as in figure 3 . 
pectedly swarmed (13/05/91, Mantes-laJolie, mean temperature $13.2^{\circ} \mathrm{C}$, no rain, wind velocity: $2.2 \mathrm{~m} / \mathrm{s}$ ).

\section{Outgoing bees}

The worker bees began to leave the hive early at $6: 45 \mathrm{~h}$ (10 bees), when the ambient temperature was $8^{\circ} \mathrm{C}$; their number increased from 8:30 h (50 bees) to $10: 20 \mathrm{~h}$ ( 1000 bees). The number of outgoing bees then decreased drastically ( 130 bees) before it rose again at 10:45 h. There was a significant increase from 11:20 (1 300 bees) which reached a peak of 6600 insects at 11:35 $\mathrm{h}$. Therefore, 19150 bees left the hive to form a swarm within a time span of only $15 \mathrm{~min}$. The number of outgoing bees then remained constant until 16:45 (1 100 bees) after which it dropped regularly until $22: 35 \mathrm{~h}$ (10 bees).

\section{Incoming bees}

The number of incoming bees increased regularly until 10:20 $\mathrm{h}$ after which it dropped until 10:40 h (140 bees). At that time, all activity was suspended for several minutes. The returns then continued until around 11:20 $\mathrm{h}$ ( 1500 bees), the time when the swarm left the colony. During swarming, the number of incoming bees was very reduced ( 400 bees), but just afterwards $(11: 35 \mathrm{~h})$ a substantial proportion of bees returned: 6500 bees within a 20-min period. As was the case for the outgoing bees, the number of incoming bees remained quite constant until 17:00 $\mathrm{h}$, then declined till 22:35 $\mathrm{h}$.

\section{Cumulative curve of bees outside the hive}

After swarming, the total number of bees outside the hive remained constant, ie around 17000 insects.
During the week following observation, 3 other swarms left the colony on the 15/05, $18 / 05$ and $20 / 05$. The flights activity patterns during these secondary swarmings were, generally speaking, the same as those observed in the primary swarms. In particular, colony activity declined sharply $1 \mathrm{~h}$ before swarming (between 45-70 min). The swarms left the colony between 13:00 and $16: 30 \mathrm{~h}$, and their numbers decreased: 11600,9000 and 5600 .

\section{Influence on colony activity of crop treatment by pesticides}

Only the data on flight activity during spraying of pesticides and soon after (around $2 \mathrm{~h}$ ) have been shown here as an example of the bee counter's potential. The data relating to the following hours and days have not been presented.

The same results were obtained for the 3 experiments (fig 6). Immediately after spraying the pesticides, the activity of the bee colony nearby became severely disturbed. The number of incoming bees increases, whereas the number of outgoing bees decreased. In particular, a peak of incoming bees was never observed under normal conditions (see, for example, fig 3).

\section{Evaluation of the counter precision}

In the flight cage, the number of honeybees remaining outside the colony for each of the 2 experiments were 422 and 675 for the manual counting, and 421 and 677 for the electronic counting for Experiments 1 and 2 , respectively. The corresponding number of flights was 1385 and 6518 , which represents an error of 0.2 and $0.3 \%$. The presence of a cage greatly reduced colony flight activity between 6 - and 33 -fold in the 2 experiments. 

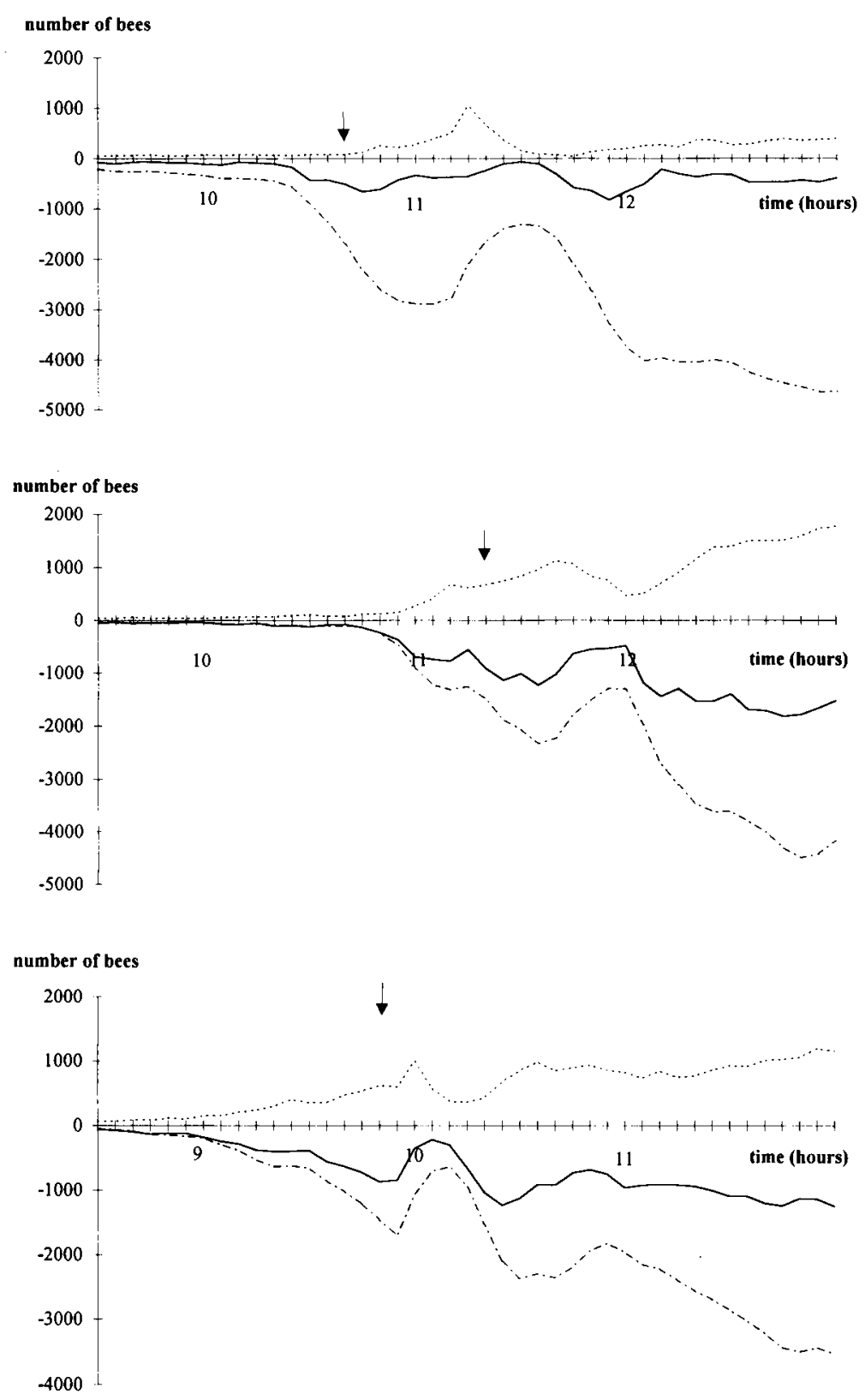

Fig 6. Influence on colony activity of crop treatment by pesticides (arrows). Top: $21 / 08 / 90$ at Châteaudun (France). Treatment with a mixture of fungicide Sportak 45 and insecticide Décis was initiated at 10:40 h. Middle: 10/05/91 at Mantes-la-Jolie (France). Treatment with a mixture of fungicide Konker and insecticide Décis was initiated at 11:20 h. Bottom: 06/05/92 at Arras (France). Treatment with a mixture of fungicide Eria and insecticide Karaté was initiated at 9:50 h. Legend as in figure 3. 


\section{DISCUSSION}

\section{The counter}

The counter appears to be well adapted to monitoring and registering an important parameter of honeybee colony activity, ie the number of incoming and outgoing bees of the hive. It presents several advantages over earlier models although it uses the same measuring principle.

Firstly, it appears well adapted for measuring normal colony activity $(50000$ bees on 10 combs) and as such is comparable to the model proposed by Rickli et al (1989). This is certainly more interesting than the devices designed to monitor small colonies on only $1 \mathrm{comb}$ (Spangler, 1969), 3 combs (Liu et al, 1990) or 5 combs (Erickson et al, 1975).

Secondly, the counting precision is superior to that of other devices for the following reasons:

- The number of in/out channels has been increased to 32 and so does not hinder bee movement to the same extent. Earlier models had a very variable number of in/out channels: 2 (Spangler, 1969), 4 (Liu et al, 1990), 7 (Erickson et al, 1975), 11 (Marletto and Piton, 1983), 12 (Burill and Dietz, 1973; Buckley et al, 1978), 16 (Rickli et al, 1989) and 24 (Peyron et al, 1990).

- The form and dimensions of the channels have been adapted to different bee behaviors in the channels, which have been previously analyzed by video recordings. Such behaviors are, for example, the comings and goings of certain bees in the channel (without necessarily leaving the colony, eg, guards), the simultaneous entrance and exit of 2 bees at each channel opening, and the very close succession of honeybees, in particular when colony activity is high.

To resolve all or some of these problems, several technical solutions were adopted.
Firstly, a slight narrowing of the channels at the level of the infrared beams (the socalled 'queue-break', see fig 2) led to a better separation between the bees which followed one another in close succession (the case for both the incoming and the outgoing bees). However, when bees followed one another at a distance $<1 \mathrm{~mm}$, the 2 bees were counted as one.

Next, earlier counters used 2 infrared beams and the detectors were fitted as closely together as possible, ie $2.5 \mathrm{~mm}$ (Rickli et al, 1989) and $5 \mathrm{~mm}$ (Liu et al, 1990). The present counter uses 1 infrared source and 1 dual photoreceptor containing the 2 detectors. In this manner the 2 detectors are separated by the small distance of $0.1 \mathrm{~mm}$ (fig 2), which increases resolution to at least $1 \mathrm{~mm}$ and even less by fine tuning.

Thirdly, the refractory period after a count has been registered and during which another count cannot be registered is very short. Because each channel is checked 2000 times/s, a second bee can be detected within a period of $0.5 \mathrm{~ms}$.

Finally, an asynchronous sequential algorithm is used to decide if a bee that has left a channel was leaving or entering the hive or, in case of erratic bee movements in the channel, to eliminate spurious counts. This algorithm is produced by a PAL-hardware program. The logic utilized by Liu et al (1990) does not meet these requirements.

A current development regarding this device is to couple the measurement on the number of incoming and outgoing bees with the recording of several meteorological parameters such as temperature, humidity, wind direction and speed.

\section{Precision and reliability study}

One reliable method to determine counter precision is to visually count the honeybees 
which leave the colony and compare this number with that given by the counter. To carry out this experiment with a normal bee colony ( 50000 bees) in a natural environment (open field) is quite impossible. Unfortunately, in a flight cage colony activity is much reduced and therefore the small calculated error of $0.2-0.3 \%$ is underestimated in the case of high activity.

The counters have been used in real field tests over periods of several months and in various weather conditions without major problems. When using battery power, counting can only be guaranteed for about $72 \mathrm{~h}$. In any case, it is important to examine the counter set-up at regular intervals since channels can become blocked by dead bees, or the infrared beam emission may become hampered by an accumulation of pollen in the channel, and these must be cleaned.

\section{Daily activity of the colony}

This counting device appears to be well suited for monitoring and registering honey bee activity at the hive entrance, in different weather conditions, and even in the case of swarming. It can be used coupled with other approaches in the study of the foraging behavior of the colony, and the influence of external factors such as the spraying of pesticides on colony life.

The number of incoming and outgoing bees of a hive is only one of the parameters of colony activity, but it cannot be directly equated with foraging activity (nectar and pollen gathering) although these are strongly related. The use of a counting device does not prevent behavioral studies from being carried out both for the colony level and for the plants visited by bees. The gathering of numerous quantitative data should not be seen as a substitute for the essential observations regarding other parameters of colony behavior. All these methods are complementary.

At present the homologation tests to predict pesticidal risks to honeybees are generally carried out under laboratory conditions and not under normal colony conditions. They assess only the acute toxicity of the pesticide and do not take into account their possible long-term effects on the behavior of the bee colony. In the future, real field tests using normal colonies equipped with bee counters could provide more comprehensive information on the actual effects of pesticides on bee colony activity.

A visual observation of swarming is not always certain (the time of swarming being brief and difficult to predict), as is the repeated swarming of the same bee colony which can occur over an interval of several days (Butler, 1609). The continuous observation of a bee colony over a long period is necessary to detect the swarms and to precisely determine the time at which they leave the colony. Moreover, it is quite impossible to accurately determine the number of outgoing bees.

The bee counter allows the detection of several swarms leaving the same colony, and the record of the principal parameters without the presence of any observer. For example, 4 swarms left a colony over an 8day period. The swarming period was from late morning to mid-afternoon, and swarming took place over a very short time period, 10-20 min. The number of bees leaving amounted to between 17000 (the first swarm) and 5600 (the last swarm), with a mean value of 10800 , which is close to the published data, ie 11800 (Fell et al, 1977) or 14000 (Burgett and Morse, 1974). The temporal pattern of several swarmings was investigated taking into account both the incoming and the outgoing bees. In particular, it confirmed that about $1 \mathrm{~h}$ before the swarm leaves the colony, colony activity decreases and remains at a low level for 
several minutes before swarming occurs (Allen, 1956).

\section{ACKNOWLEDGMENTS}

We would like to thank $K$ Bishay and $N$ Fornier (ITAPI), R Carcel (CFPPA, Arras), and R Baumeister (PROCIDA) for their technical assistance and AM Audoire for her assistance in the English version of the manuscript.

\section{Résumé - Mesure de l'activité de vol des abeilles à l'entrée de la ruche au moyen d'un microprocesseur. Un des} paramètres les plus importants permettant d'évaluer l'activité d'une colonie d'abeilles est l'évolution, au cours du temps, du nombre des entrées et des sorties d'insectes de leur ruche. Le compteur présenté ici est contrôlé par un microprocesseur, et présente plusieurs avantages par rapport aux dispositifs précédemment décrits. Il est bien adapté aux dimensions d'une ruche standard (à 10 cadres), et comporte 32 canaux bidirectionnels. Les détecteurs à infra-rouge présents dans chaque canal ne sont séparés que de $0,1 \mathrm{~mm}$, et sont contrôlés par un algorithme séquentiel asynchrone qui augmente la précision du compteur. Des résultats de mesure de l'activité journalière d'une colonie d'abeilles placée dans différentes conditions sont présentés ici à titre d'exemples. Par un jour ensoleillé (fig 3 ), les ouvrières ont commencé à quitter la ruche à $8 \mathrm{~h} 30$ et ont présenté un maximum d'activité entre $13 \mathrm{~h} 45$ et $17 \mathrm{~h}$; leur activité a cessé aux alentours de $21 \mathrm{~h} 45$. Le nombre total de vols enregistrés a été de 127 859. Par temps nuageux (fig 4), l'activité a été faible, et le nombre de vol total a été de 17 303. Le dispositif de comptage a même permis de détecter 4 essaims provenant d'une même colonie, au cours d'une période de $8 \mathrm{j}$; ils comportaient de 17000 (1 ${ }^{\mathrm{er}}$ essain, fig 5 ) à 5600 abeilles (dernier essaim). Ce compteur apparaît également bien adapté à l'étude de l'influence, sur les colonies d'abeilles, du traitement des cultures par des pesticides (fig 6), et pourrait apporter, dans l'avenir, des informations capitales sur les effets réels de ces traitements.

activité de vol / actographe / essaimage / pesticide

Zusammenfassung - Mikroprozessorgesteuerte Erfassung der Flugaktivität von Honigbienen am Flugloch. Ein wichtiger Parameter für die Beurteilung der Aktivität eines Bienenvolkes ist die zeitliche Erfassung der Anzahl ein- und ausfliegender Bienen. Der hier beschriebene mikroprozessorgesteuerte Zähler besitzt gegenüber früheren Zählapparaten wesentliche Vorteile. Der Zähler paßt zu den Standardbeutenmaßen (10 Rähmchen) und ermöglicht den Zugang zu den Völkern durch 32 in beiden Richtungen benutzbare Kanäle. Die kleinen Infrarotdetektoren in jedem dieser Kanäle sind nur $0,1 \mathrm{~mm}$ voneinander getrennt und werden von einem asynchronen sequenziellen Algorithmus gesteuert, der die Genauigkeit des Zählers verbessert. Die Ergebnisse von Zählungen der täglichen Aktivität eines Honigbienenvolkes wurden unter unterschiedlichen Bedingungen erfaßt. An einem sonnigen Tag verließen die ersten Bienen um 8.30 h das Bienenvolk (Abb 3). Die Hauptaktivitätszeit war zwischen $13.45 \mathrm{~h}$ und $17.00 \mathrm{~h}$, der Flug wurde etwa um $21.45 \mathrm{~h}$ eingestellt. Insgesamt fanden 127859 Ausflüge statt. An einem kalten, wolkigen Tag war die Aktivität gering ( $\mathrm{Abb} 4)$ und es fanden insgesamt nur 17303 Ausflüge statt. Der Bienenzähler ermöglichte die Entdeckung von 4 Schwärmen desselben Volkes innerhalb von 8 Tagen. Die Anzahl ausschwärmender Bienen betrug zwischen 17000 im ersten und 5600 im letzten Schwarm (Abb 5). Der Bienenzähler ist offenbar gut geeignet, den Einfluß von Pflanzenschutzmaßnahmen auf 
die Bienenaktivität festzustellen (Abb 6) und könnte in Zukunft klarere Informationen über die tatsächliche Auswirkung solcher Behandlungen liefern.

\section{Flugaktivität / Zähleinrichtung / Mikro- prozessor}

\section{REFERENCES}

Allen MD (1956) The behaviour of honeybees preparing to swarm. Br J Anim Behav 4, 14-22

Brittain WH (1933) Apple pollination studies in the Annapolis Valley, NS, Canada, 1928-32. Can Dept Agric Bull 162, 119-125

Buckley GA, Davies LG, Spindley DT (1978) A bee counter for monitoring bee activity and bee behaviour. Br J Pharmacol 64, 475

Burgett DM, Morse RA (1974) The time of natural swarming in honey bees. Ann Entomol Soc Am 67, 719720

Burrill RM, Dietz A (1973) An automatic honey bee counting and recording device for possible systems analysis of a standard colony. Am Bee J 113, 216-218

Butler C (1609) The Feminine Monarchie. Oxford, Barnes
Chauvin R (1976) Sur la mesure de l'activité des abeilles au trou de vol d'une ruche à 10 cadres. Insectes Soc 35, 75-82

Erickson EH, Miller HH, Sikkema DJ (1975) A method for separating and monitoring honeybee flight activity at the hive entrance. J Apic Res 14, 119-125

Fell RD, Ambrose JT, Burgett DM, De Jong D, Morse RA, Seeley TD (1977) The seasonal cycle of swarming in honey bees. J Apic Res 16, 170.173

Liu C, Leonard JJ, Feddes JJ (1990) Automated monitoring of flight activity at a beehive entrance using infrared light sensors. J Apic Res 29, 20-27

Marletto F, Piton P (1983) Conta-api elettronico per la verifica dell'attività degli alveari. Apic $\operatorname{Mod} 74,137$ 141

Peyron JM, Marceau J, Boily R (1990) Mesurer l'activité des colonies. Ouest Apic, 10-11

Pickard RS, Hepworth D (1979) A method for electronically monitoring the ambulatory activity of honeybees under dark conditions. Behav Res Methods Instrumentation 11, 433-436

Rickli M, Bühlmann $G$, Gerig $L$, Herren $H_{1}$ Schürch $H J$, Zeier W, Imdorf A (1989) Zur Anwendung eines elektronischen Bienenzähigerätes am Flugloch eines Bienenvolkes. Apidologie 20, 305-315

Spangler HG (1969) Photoelectrical counting of outgoing and incoming honey bees. J Econ Entomol $62,1183-1184$ 